\title{
THE EFFECT OF MURĀBAHAH AND MUSYĀRAKAH FINANCING DISTRIBUTION ON OPERATIONAL REVENUE OF PEOPLE'S FINANCING BANK SHARIA 2015-2018
}

\author{
Yakinah $^{1}$, Kamaluddin ${ }^{2}$, Arti Damisa ${ }^{3}$, Sulaiman $^{4}$ \\ ${ }^{1}$ IAIN Padangsidimpuan (Perbankan Syariah, FEBI, IAIN Padangsidimpuan) \\ ${ }^{2}$ IAIN Padangsidimpuan (Hukum Syariah, FEBI, IAIN Padangsidimpuan) \\ ${ }^{3}$ IAIN Padangsidimpuan (Perbankan Syariah, FEBI, IAIN Padangsidimpuan) \\ ${ }^{4}$ IAIN Padangsidimpuan (Perbankan Syariah, FEBI, IAIN Padangsidimpuan) \\ ${ }^{5}$ IAIN Padangsidimpuan (Perbankan Syariah, FEBI, IAIN Padangsidimpuan) \\ yakinah@gmail.com ${ }^{1}$, kamaluddin@iain-padangsidimpuan.ac.id ${ }^{2}$, arti@iain-padangsidimpuan.ac.id $^{3}$ \\ sulaiman@iain-padangsidimpuan.ac.id ${ }^{4}$
}

\begin{abstract}
ABSTRAK
Penelitian ini bertujuan untuk mengetahui pengaruh penyaluran pembiayaan Murābahah dan Musyārakah terhadap pendapatan operasional. Sampel yang digunakan dari data Laporan Keuangan yang diterbitkan oleh Otoritas Jasa Keuangan pada Bank Pembiayaan Rakyat Syariah Tahun 2015-2018. Metode yang digunakan adalah metode Regresi Linear Berganda. Hasil statistik menunjukkan bahwa pembiayaan Murābahah dan Musyārakah mempunyai pengaruh yang positif dengan pendapatan operasional.

Kata Kunci: Pembiayan Murābahah, Pembiayaan Musyārakah, Pendapatan Operasional

\section{ABSTRACT}

This research aimed to determine the effect of Murābahah and Musyārakah financing distribution on operating income. This research use the reporting finance by the financial fervices authority of people's finance Bank Syariah in 2015-2018 as a sample. It used double linear regression method. The result shows that Murābahah and Musyārakah finance have a positive influence on operating income.
\end{abstract}

Keywords: Murābahah, Musyārakah, operating income

\section{A. PENDAHULUAN}

Perkembangan perbankan syariah di Indonesia saat ini semakin meningkat sejak adanya Undang-Undang No. 21 Tahun 2008 tentang perbankan syariah yang memberikan landasan operasi yang lebih jelas bagi bank syariah menunjukkan bahwa dilakukannya amandemen Undang-Undang menjadi No.7 Tahun 1992 menjadi Undang-Undang No.10 Tahun 1998 direspon baik oleh pelaku industri perbankan salah satu diantaranya yaitu Bank Pembiayaan Rakyat Syariah (BPRS).

$$
\text { Bank Pembiayaan Rakyat Syariah }
$$

adalah bank yang melaksanakan kegiatan usaha 
berdasarkan prinsip syariah yang dalam kegiatannya tidak memberikan jasa dalam lalu lintas pembayaran. Lembaga keuangan ini sangat dibutuhkan oleh masyarakat di daerah pedesaan atau pinggiran yang belum terjangkau oleh Bank Umum, baik dari segi penyimpanan dana nasabah maupun segi penyaluran pembiayaan.

$$
\text { Sebagai lembaga intermediasi, }
$$
pembiayaan yang disalurkan oleh Bank Pembiayaan Rakyat Syariah dengan berbagai akad akan mempengaruhi pendapatan operasional, diantaranya dalam penelitian ini adalah pembiayaan Murābahah dan Musyārakah. Oleh karena itu Bank Pembiayaan Rakyat Syariah harus memperhatikan perkembangan pendapatan operasionalnya.

Mengacu kepada petunjuk Al-Qur'an, tentang pembiayaan Murābahah terdapat pada Q.S Al-Baqarah ayat 275 yang intinya: bahwa pada awalnya orang-orang yang suka mengambil riba mengatakan bahwa jual beli itu sama dengan riba. Sekilas praktik jual beli dan riba memang hampir mirip karena sama-sama adanya tambahan (ziyadah) yaitu nilai lebih dari pokoknya. Hanya saja jual beli disebut margin dalam pertukaran barang ribawi. Ayat ini kemudian menegaskan bahwa Allah menghalalkan jual beli dan mengharamkan riba. Dengan pengertian bahwa pada jual beli ada pertukaran atau penggantian yang seimbang yaitu barang dari pihak penjual kepada pembeli. Sedangkan pada riba tidak ada penyeimbangan langsung kecuali kesempatan pemanfaatan uang. Dan pada pembiayaan Musyārakah ayat yang berhubungan yaitu pada Q.S Shad ayat 24 yang menyatakan: bahwa etika dasar dalam perserikatan yaitu pertama, memilih partner yang beriman dan shaleh, kedua, memiliki perhitungan yang jelas, ketiga, dapat dipercaya sehingga tidak saling mengkhianati dan keempat, apabila terjadi sengketa sudah semestinya diselesaikan dengan cara baik dengan bantuan pihak lain.

Pengoperasiannya, Murābahah merupakan produk finansial yang berbasis ba'i atau jual beli. Akad murābahah adalah produk pembiayaan yang paling banyak digunakan oleh perbankan syariah di dalam kegiatan usaha. Murābahah menduduki porsi $66 \%$ dari semua transaksi investasi bank-bank syariah di dunia. Sedangkan Akad musyārakah digunakan bank untuk memfasilitasi pemenuhan kebutuhan permodalan bagi nasabah guna menjalankan usaha atau proyek dengan cara melakukan pernyataan modal bagi usaha atau proyek yang bersangkutan.

\section{B. METODE}

Jenis penelitian adalah penelitian kuantitatif, dengan menggunakan data sekunder, dengan menggunkan desain sampling jenuh, sampel sebanyak 48 sampel yaitu diambil dari laporan bulanan penyaluran pembiayaan murābahah, musyārakah dan pendapatan operasional Bank Pembiayaan Rakyat Syariah dari tahun 2015-2018 yang dipublikasikan oleh otoritas jasa keuangan melalui website www.ojk.go.id. 
Lokasi penelitian ini dilakukan pada Bank Pembiayaan Rakyat Syariah Indonesia dengan rentang waktu 2015-2018. Penelitian dilakukan mulai dari bulan Februari sampai dengan bulan September 2019.

Variabel yang digunakan dalam penelitian ini adalah: 1) variabel bebas yaitu pembiayaan murābahah dan pembiayaan musyārakah, 2) variabel terikat yaitu pendapatan operasional.

Upaya yang dilakukan dalam rangka pengumpulan data untuk melengkapi penulisan ini digunakan teknik pengumpulan data sebagai berikut: 1) studi kepustakaan, dan 2) dokumentasi.

Untuk mengetahui pengaruh penyaluran pembiayaan murābahah dan musyārakah terhadap pendapatan operasional Bank Pembiayaan Rakyat Syariah Tahun 2015-2018, maka peneliti menggunakan analisis dengan metode uji deskriptif, uji linearitas, uji normalitas, uji asumsi klasik, regresi linear berganda dan uji hipotesis data diolah menggunakan program komputer SPSS versi 23.

\section{HASIL DAN PEMBAHASAN}

Uji variabel Y (Pendapatan Operasional)

Berikut ini adalah pendapatan operasional Bank Pembiayaan Rakyat Syariah di Indonesia pada Januari 2015 sampai Desember 2018 dapat dilihat pada tabel di bawah ini:

Tabel C.1
POINT Vol. 1, No. 1, Jul 2020

Pendapatan Operasional Bank Pembiayaan Rakyat Syariah Tahun

2015-2018

(dalam Jutaan Rupiah)

\begin{tabular}{|c|c|c|c|c|}
\hline \multirow{2}{*}{ BULAN } & \multicolumn{4}{|c|}{ TAHUN } \\
\cline { 2 - 5 } & 2015 & 2016 & 2017 & 2018 \\
\hline Januari & 93.876 & 114.308 & 137.479 & 151.881 \\
\hline Februari & 185.571 & 219.765 & 248.745 & 277.585 \\
\hline Maret & 283.607 & 328.416 & 377.734 & 421.972 \\
\hline April & 380.863 & 438.320 & 502.433 & 561.657 \\
\hline Mei & 478.297 & 552.055 & 633.810 & 710.802 \\
\hline Juni & 579.400 & 669.466 & 762.427 & 854.191 \\
\hline Juli & 678.323 & 773.837 & 897.953 & 1.005 .340 \\
\hline Agustus & 779.675 & 903.881 & 1.037 .126 & 1.158 .992 \\
\hline September & 882.572 & 1.015 .540 & 1.169 .342 & 1.308 .236 \\
\hline Oktober & 987.861 & 1.138 .416 & 1.306 .060 & 1.459 .214 \\
\hline November & 1.093 .499 & 1.263 .228 & 1.446 .088 & 1.613 .583 \\
\hline Desember & 1.212 .905 & 1.391 .233 & 1.590 .687 & 1.781 .691 \\
\hline
\end{tabular}

Sumber: www.ojk.go.id data diolah peneliti

Berdasarkan tabel C.1 di atas, menunjukkan adanya peningkatan pendapatan operasional Bank Pembiayaan Rakyat Syariah dari tahun 2015 sampai 2018, pendapatan operasional yang dihasilkan Bank Pembiayaan Rakyat Syariah setiap tahunnya mengalami peningkatan dan Bank Pembiayaan Rakyat Syariah telah berhasil dalam memenuhi target yang telah ditetapkan.

Uji Variabel X1 (Pembiayaan Murābahah)

Berikut ini data bulanan penyaluran pembiayaan murābahah yang dilakukan Bank Pembiayaan Rakyat Syariah yang terjadi pada tahun 2015 hingga 2018.

Tabel C.2

Penyaluran pembiayaan Murābahah Bank Pembiayaan Rakyat Syariah Tahun 2015-2018 (dalam Jutaan Rupiah)

\begin{tabular}{|c|c|c|c|c|}
\hline \multirow{2}{*}{ BULAN } & \multicolumn{4}{|c|}{ TAHUN } \\
\cline { 2 - 5 } & 2015 & 2016 & 2017 & 2018 \\
\hline Januari & 3.990 .39 & 4.508 .50 & 5.097 .88 & 5.964 .91 \\
\hline
\end{tabular}




\begin{tabular}{|c|c|c|c|c|}
\hline & 4 & 0 & 3 & 2 \\
\hline Februari & 4.054 .03 & 4.576 .63 & 5.212 .26 & 6.067 .53 \\
& 4 & 3 & 7 & 2 \\
\hline Maret & 4.132 .43 & 4.626 .94 & 5.312 .96 & 6.204 .18 \\
& 0 & 1 & 9 & 7 \\
\hline April & 4.212 .14 & 4.717 .87 & 5.423 .22 & 6.368 .35 \\
& 7 & 5 & 0 & 2 \\
\hline Mei & 4.281 .50 & 4.834 .72 & 5.566 .97 & 6.523 .20 \\
& 5 & 8 & 7 & 3 \\
\hline Juni & 4.367 .72 & 4.927 .90 & 5.651 .45 & 6.487 .52 \\
& 7 & 3 & 6 & 0 \\
\hline Juli & 4.355 .74 & 4.881 .05 & 5.633 .11 & 6.539 .38 \\
& 8 & 9 & 2 & 8 \\
\hline Agustus & 4.379 .30 & 4.924 .87 & 5.669 .96 & 6.576 .97 \\
& 6 & 3 & 9 & 9 \\
\hline Septem & 4.403 .58 & 4.887 .37 & 5.697 .83 & 6.621 .86 \\
ber & 2 & 0 & 7 & 7 \\
\hline Oktober & 4.417 .10 & 4.913 .79 & 5.760 .22 & 6.716 .83 \\
& 8 & 7 & 0 & 1 \\
\hline Novemb & 4.443 .95 & 4.982 .79 & 5.806 .30 & 6.815 .75 \\
er & 5 & 6 & 7 & 0 \\
\hline Desemb & 4.491 .69 & 5.053 .76 & 5.904 .75 & 6.940 .37 \\
er & 7 & 4 & 1 & 9 \\
\hline
\end{tabular}

Sumber: www.ojk.go.id

Berdasarkan tabel C.2 di atas, penyaluran pembiayaan murābahah yang diberikan Bank Pembiayaan Rakyat Syariah di tahun 2015 mengalami peningkatan setiap bulannya kecuali pada bulan Juli sebesar 0,27 persen, kemudian meningkat kembali pada bulan selanjutnya. Terjadi penurunan pada bulan Juli dan September 2016 masing-masing sebesar 0,95 persen dan 0,76 persen. Tahun 2017 pada bulan Juli mengalami penurunan sebesar 0,32 persen dan tahun 2018 terjadi penurunan pada bulan Juni sebesar 0,55 persen.

\section{Uji Variabel X2 (Pembiayaan Musyārakah)}

Berbeda halnya dengan pembiayaan murābahah yang merupakan pembiayaan berbasis jual beli, pembiayaan musyārakah merupakan pembiayaan berbasis bagi hasil (profit and loss sharing), dimana kedua belah pihak yang berserikat saling bekerja sama dalam mengelola usahanya. Berikut ini dapat dilihat data bulanan dari penyaluran pembiayaan musyārakah dari tahun 2015-2018 sebagai berikut:

Tabel C.3

Penyaluran pembiayaan Musyārakah Bank Pembiayaan Rakyat Syariah Tahun 2015-2018

(dalam Jutaan Rupiah)

\begin{tabular}{|l|c|c|c|c|}
\hline \multirow{2}{*}{ BULAN } & \multicolumn{4}{|c|}{ TAHUN } \\
\cline { 2 - 5 } & 2015 & 2016 & 2017 & 2018 \\
\hline Januari & 537.147 & 619.498 & 739.562 & 725.859 \\
\hline Februari & 551.971 & 636.628 & 758.403 & 718.423 \\
\hline Maret & 572.606 & 671.658 & 783.045 & 737.620 \\
\hline April & 582.366 & 710.929 & 778.793 & 751.665 \\
\hline Mei & 603.277 & 737.375 & 807.477 & 779.759 \\
\hline Juni & 613.206 & 764.862 & 826.667 & 787.075 \\
\hline Juli & 618.794 & 762.266 & 807.454 & 789.533 \\
\hline Agustus & 633.793 & 775.947 & 813.934 & 795.641 \\
\hline September & 647.545 & 784.274 & 794.946 & 809.215 \\
\hline Oktober & 657.544 & 796.235 & 801.512 & 808.636 \\
\hline November & 677.303 & 797.621 & 806.589 & 829.804 \\
\hline Desember & 652.316 & 774.949 & 776.696 & 837.915 \\
\hline
\end{tabular}

Sumber: www.ojk.go.id

Berdasarkan tabel C.3 di atas, penyaluran pembiayaan musyārakah pada Bank Pembiayaan Rakyat Syariah tahun 2015 mengalami peningkatan setiap bulannya kecuali pada bulan Desember mengalami penurunan secara signifikan sebesar 3,69 persen. Pada tahun 2016 mengalami peningkatan kecuali pada bulan Juli dan Desember masing-masing sebesar 0,34 persen dan 2,84 persen. Pada tahun 2017 terjadi penurunan pada bulan April, Juli, September dan Desember masing-masing sebesar 0,54 persen, 2,32 persen, 2,33 persen dan 3,70 persen. Kemudian pada tahun 2018 mengalami peningkatan setiap bulannya kecuali pada bulan Februari dan Oktober masingmasing sebesar 1,02 persen dan 0,07 persen.

Perhitungan Uji Analisis Deskriptif 
Table C.4

Hasil Uji Analisis Deskriptif Descriptive Statistics

\begin{tabular}{|c|r|r|c|r|c|}
\hline & $\mathrm{N}$ & $\begin{array}{r}\text { Mini } \\
\text { mum }\end{array}$ & $\begin{array}{c}\text { Maximu } \\
\mathrm{m}\end{array}$ & Mean & $\begin{array}{c}\text { Std. } \\
\text { Deviation }\end{array}$ \\
\hline Mr & 48 & 3990 & 6940379 & 529020 & 860764,9 \\
& & 2,92 & 19 \\
Ms & 48 & 5371 & 837915 & 730131 & 83903,91 \\
& 47 & & 794 & 0 \\
PO & 48 & 9387 & 1781691 & 788748 & 453976,4 \\
& & 6 & &, 79 & 66 \\
Valid N & 48 & & & & \\
(listwise) & & & & & \\
\hline
\end{tabular}

Sumber: Hasil Output SPSS Versi 23, data diolah

Berdasarkan tabel C.4 diketahui bahwa jumlah sampel (N) sebanyak 48. Rata-rata pendapatan operasional sebesar 788748,79 , nilai minimum pendapatan operasional sebesar 93876, nilai maksimum pendapatan operasional sebesar 1781691, nilai standar pendapatan operasional sebesar 453976,466. Rata-rata pembiayaan murābahah sebesar 5290202,92, nilai minimum pembiayaan murābahah sebasar 3990394, nilai maksimum pembiayaan murābahah sebesar 6940379, nilai standar pembiayaan murābahah sebesar 860764.919. Rata-rata pembiayaan musyārakah sebesar 730131.94, nilai minimum pembiayaan musyārakah sebesar 537147, nilai maksimum pembiayaan musyārakah sebesar 837915 , nilai standar pembiayaan musyārakah sebesar 83903.910.

Perhitungan Uji Linearitas

Tabel C.5

Hasil Uji Linearitas Pembiayaan

Murābahah
POINT Vol. 1, No. 1, Jul 2020

ANOVA

\begin{tabular}{|c|r|r|r|r|r|}
\hline & $\begin{array}{c}\text { Sum of } \\
\text { Squares }\end{array}$ & df & $\begin{array}{c}\text { Mean } \\
\text { Square }\end{array}$ & F & Sig. \\
\hline Regress & $\begin{array}{r}346875911 \\
\text { ion }\end{array}$ & 1 & $\begin{array}{r}3468759 \\
112037 .\end{array}$ & 25.5 & \\
& 2037.525 & & 53 & .000 \\
& & & 1357472 & & \\
Residua & 624437382 & 46 & 57111.7 & & \\
I & 7138.391 & & 04 & & \\
Total & 971313293 & 47 & & & \\
& 9175.916 & 4 & & & \\
\hline
\end{tabular}

$\mathrm{R}=0,478 \quad$ Std.error estimate $=403667,245$ $\mathrm{R}$ Square $=0,228$ Independent variable $=\mathrm{Mr}$ Adjusted R Square $=0,212$

Sumber: Hasil Output SPSS Versi 23, data diolah

Berdasarkan hasil output SPSS untuk variabel pembiayaan murābahah menunjukkan nilai R2 sebesar 0,228 dengan jumlah sampel (n) sebanyak 48. Maka besarnya nilai c2hitung = $48 \times 0,228=10,944$. Nilai ini dibandingkan dengan $d f=46$ dan tingkat signifikansi 0,05 didapat nilai c2tabel sebesar 62,82962. Karena nilai c2hitung < c2tabel $(10,944<62,82962)$, maka dapat disimpulkan bahwa model linear diterima.

Tabel C.6

Hasil Uji Linearitas Pembiayaan

Musyārakah

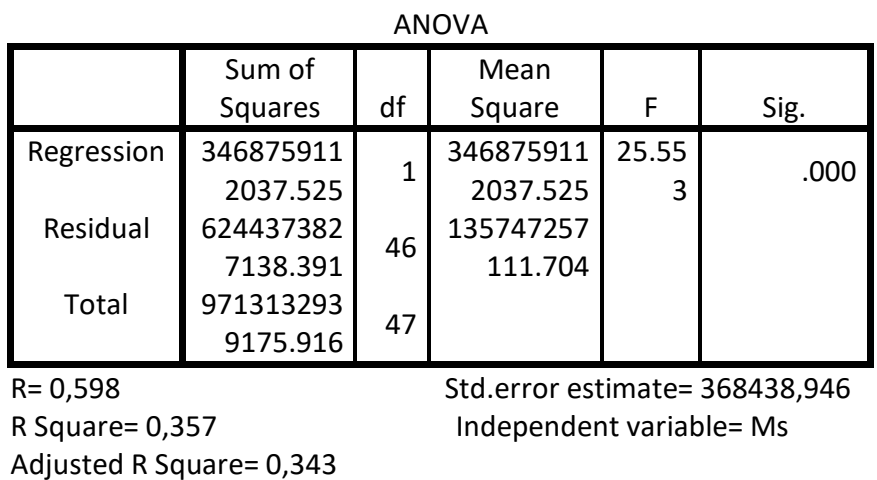

Sumber: Hasil Output SPSS Versi 23, data diolah

Berdasarkan hasil output SPSS untuk variabel pembiayaan musyārakah menunjukkan nilai $R^{2}$ sebesar 0,357 dengan jumlah sampel ( $n$ ) 
sebanyak 48. Maka besarnya nilai $\mathrm{c} 2$ hitung = $48 \times 0,357=17,136$. Nilai ini dibandingkan dengan $\mathrm{df}=46$ dan tingkat signifikansi 0,05 didapat nilai c2 tabel sebesar 62,82962. Karena nilai c2 hitung < c2 tabel $(17,136<62,82962)$, maka dapat disimpulkan bahwa model linear diterima.

Perhitungan Uji Normalitas

\section{Gambar C.1}

Uji Normalitas

Normal P-P Plot of Regression Standardized Residual

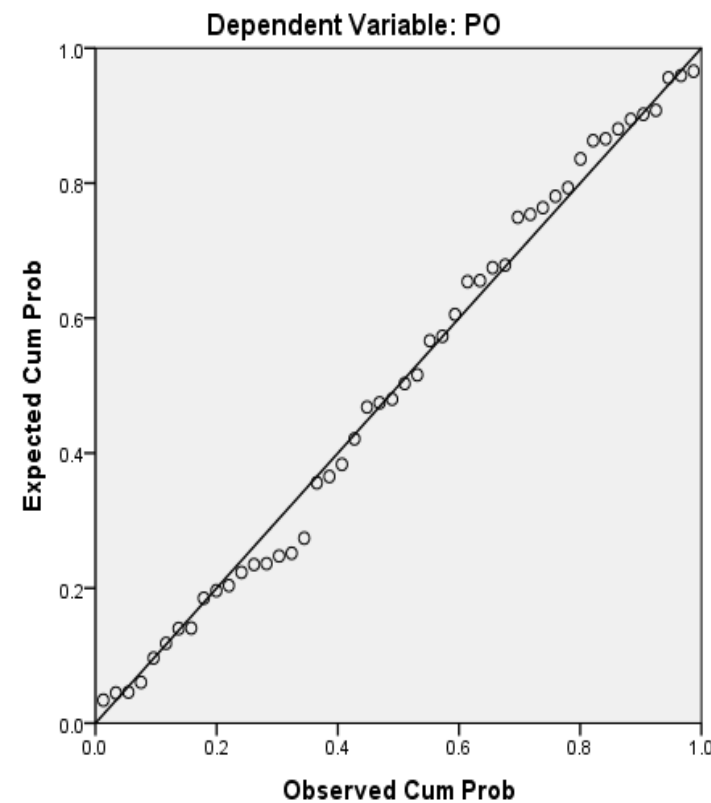

Dari gambar di atas dapat diketahui bahwa titik-titik menyebar sekitar garis diagonal, maka nilai residual tersebut berdistribusi normal.

Perhitungan Uji Asumsi Klasik

Uji Multikolinearitas

Tabel C.7

Uji Multikolinearitas

Coefficientsa

\begin{tabular}{|c|r|r|}
\hline \multirow{2}{*}{ Model } & \multicolumn{2}{|c|}{ Collinearity Statistics } \\
\cline { 2 - 3 } & Tolerance & \multicolumn{2}{|c|}{ VIF } \\
\hline (Constant) & & \\
Mr &, 385 & \\
Ms &, 385 & 2,599 \\
\hline
\end{tabular}

Sumber: Hasil Output SPSS Versi 23, data diolah

Berdasarkan output pengujian multikolinearitas tabel C.7 di atas, diketahui bahwa nilai dari Variance Inflation Factor (VIF) dari pembiayaan murābahah dan musyārakah = 2.599 dan $2.599<10$ dan nilai Tolerance dari pembiayaan murābahah dan musyārakah = 0,385 dan 0,385 >0,10. Hal ini menunjukkan bahwa antara variabel pembiayaan murābahah dan musyārakah tidak terjadi multikolinearitas.

Uji Autokorelasi

Tabel C.8

Uji Autokorelasi

\begin{tabular}{|c|c|r|r|r|r|}
\hline Model & $\mathrm{R}$ & $\begin{array}{c}\mathrm{R} \\
\text { Square }\end{array}$ & $\begin{array}{r}\text { Adjusted } \\
\text { R Square }\end{array}$ & $\begin{array}{r}\text { Std. Error } \\
\text { of the } \\
\text { Estimate }\end{array}$ & $\begin{array}{c}\text { Durbin- } \\
\text { Watson }\end{array}$ \\
\hline 1 &, $598 \mathrm{a}$ &, 357 &, 329 & $\begin{array}{r}371945,4 \\
87\end{array}$ &, 717 \\
\hline
\end{tabular}

Sumber: Hasil Output SPSS Versi 23, data diolah

Berdasarkan output di atas, maka dapat dijelaskan bahwa nilai DW sebesar 0,717 sedangkan nilai Du sebesar 1,6148 jadi (4$0,717) \geq 1,6148=3,283 \geq 1,6148$. Jadi dapat disimpulkan tidak terjadi autokorelasi.

Uji Heterokedastisitas

\section{Gambar C.2}

Uji Heteroskedastisitas

Scatterplot

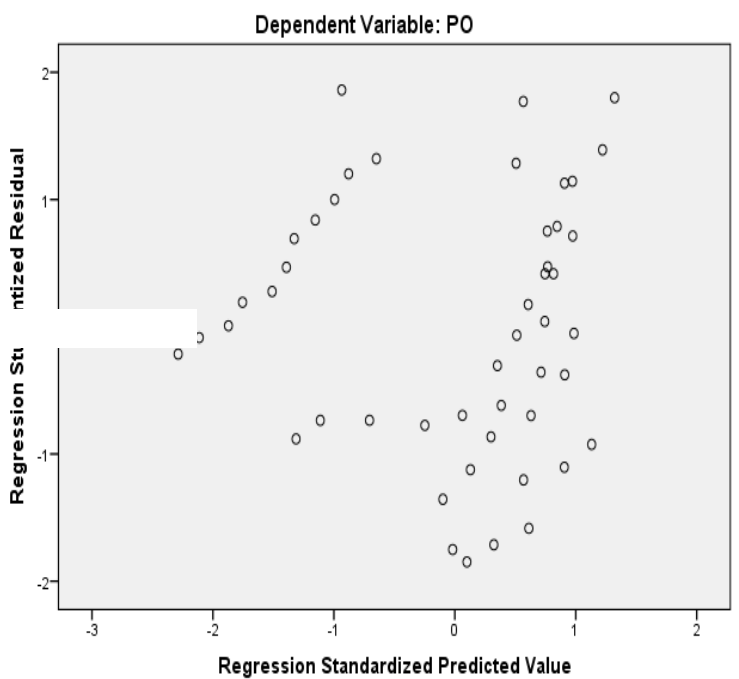


Yakinah ${ }^{1}$, Kamaluddin ${ }^{2}$, Arti Damisa ${ }^{3}$, Sulaiman ${ }^{4}$

Sumber: Hasil Output SPSS Versi 23, data diolah Berdasarkan output di atas, dapat diketahui bahwa titik-titik tidak membentuk pola yang jelas dan titik-titik menyebar di atas dan di bawah angka 0 pada sumbu Y. Jadi dapat disimpulkan bahwa tidak terjadi masalah heteroskedastisitas pada model regresi.

Perhitungan Uji Regresi Linear Berganda

Tabel C.9

Analisis Regresi Linear Berganda

\begin{tabular}{|c|r|r|}
\hline \multirow{2}{*}{ Model } & \multicolumn{2}{c|}{ Unstandardized Coefficients } \\
\cline { 2 - 3 } & \multicolumn{1}{|c|}{ B } & \multicolumn{1}{c|}{ Std. Error } \\
\hline (Constant) & $-1564555,957$ & 478863,930 \\
Mr &, 013 &, 102 \\
Ms & 3,132 & 1,042 \\
\hline
\end{tabular}

Sumber: Hasil Output SPSS Versi 23, data diolah

Berdasarkan tabel C.9 di atas menggambarkan persamaan regresi untuk mengetahui nilai konstan. Persamaan dalam penelitian ini adalah:

$\mathrm{PO}=-1564555,957+0,013 \mathrm{Mr}+3,132 \mathrm{Ms}+$ 478863,930e

Keterangan:

PO : Pendapatan operasional

a : konstanta

b1, b2: koefisien regresi

$\mathrm{Mr}$ : Pembiayaan Murabahah

Ms : Pembiayaan

e : error

Penjelasan persamaan di atas adalah sebagai berikut:

a. Nilai konstanta dari Understandardized Coefficients dalam persamaan penelitian ini adalah $-1564555,957$. Jika
POINT Vol. 1, No. 1, Jul 2020

musyārakah diasumsikan 0 maka

pendapatan operasional sebesar

$-1564555,957$ rupiah, artinya

perusahaan akan mengalami kerugian.

b. Nilai pembiayaan murābahah bernilai positif yaitu 0,013 , artinya bahwa setiap peningkatan pembiayaan murābahah sebesar 1 rupiah dan variabel lain tetap maka akan meningkatkan pendapatan operasional sebesar 0,013 rupiah. Koefisien bersifat positif artinya terjadi hubungan positif antara pembiayaan murābahah dengan pendapatan operasional.

c. Nilai pembiayaan musyārakah bernilai positif yaitu 3,132 artinya bahwa setiap peningkatan pembiayaan musyārakah sebesar 1 rupiah dan variabel lain tetap maka akan meningkatkan pendapatan operasional sebesar 3,132rupiah. Koefisien bersifat positif artinya terjadi hubungan positif antara pembiayaan musyārakah dengan pendapatan operasional.

d. Nilai error dalam penelitian ini adalah 478863,930.

Perhitungan Uji Hipotesis

Uji Koefisien Determinasi (R2)

Tabel C.10

Uji Koefisien Determinasi (R2)

\begin{tabular}{|c|c|r|r|r|r|}
\hline Model & $\mathrm{R}$ & $\begin{array}{c}\mathrm{R} \\
\text { Square }\end{array}$ & $\begin{array}{c}\text { Adjusted } \\
\text { R Square }\end{array}$ & $\begin{array}{c}\text { Std. Error of } \\
\text { the Estimate }\end{array}$ & $\begin{array}{c}\text { Durbin- } \\
\text { Watson }\end{array}$ \\
\hline 1 &, $598 \mathrm{a}$ &, 357 &, 329 & 371945,487 &, 717 \\
\hline
\end{tabular}

Sumber: Hasil Output SPSS Versi 23, data diolah 
Berdasarkan tabel C.10 diketahui bahwa nilai $\mathrm{R}$ Square sebesar 0,357. Nilai R Square tersebut berarti bahwa pembiayaan murābahah dan musyārakah mampu menjelaskan pendapatan operasional sebesar 0,357 atau 35,7\%, dan sisanya 64,3\% dijelaskan variabel lain yang tidak dimasukkan dalam penelitian ini. Dalam arti bahwa masih ada variabel independen lain yang mempengaruhi pendapatan operasional.

Uji Koefisien Regresi Secara Parsial (Uji t)

Tabel C.11

Uji Koefisien Regresi Secara

Parsial (Uji-t)

\begin{tabular}{|c|r|r|}
\hline & & \multicolumn{2}{c|}{ Coefficientsa } \\
Model & $\mathrm{T}$ & Sig. \\
\hline (Constant) & $-3,267$ &, 002 \\
Mr &, 124 &, 902 \\
Ms & 3,004 &, 004 \\
\hline
\end{tabular}

Sumber: Hasil Output SPSS Versi 23, data diolah

Berdasarkan output di atas maka dapat disimpulkan sebagai berikut:

1) Uji parsial pembiayaan murābahah dengan tingkat signifikansi 0,05. Nilai thitung pembiayaan murābahah diketahui sebesar 0,124 dan nilai ttabel 2,01410. Tabel distribusi t dapat dilihat pada tabel statistik signifikansi 0,05 dengan derajat kebebasan (df) n-k-1 atau 48-2-1= 45 (n adalah jumlah sampel dan $\mathrm{k}$ adalah jumlah variabel independen). Hasil analisis uji-t menunjukkan bahwa variabel pendapatan operasional memiliki thitung $<$ ttabel $(0,124<2,01410)$, maka dapat disimpulkan Hipotesis ditolak, artinya secara parsial variabel pembiayaan murābahah tidak memiliki pengaruh terhadap pendapatan operasional Bank Pembiayaan Rakyat Syariah tahun 2015-2018.

2) Uji parsial pembiayaan musyārakah dengan tingkat signifikansi 0,05. Nilai thitung pembiayaan musyārakah diketahui sebesar 3,004 dan nilai ttabel 2,01410. Tabel distribusi t dapat dilihat pada tabel statistik signifikansi 0,05 dengan derajat kebebasan (df) n-k-1 atau 48-2-1= 45 (n adalah jumlah sampel dan $\mathrm{k}$ adalah jumlah variabel independen). Hasil analisis uji-t menunjukkan bahwa variabel pembiayaan musyārakah memiliki thitung $>$ ttabel $(3,004>2,01410)$ maka dapat disimpulkan Hipotesis diterima, artinya secara parsial variabel pembiayaan musyārakah berpengaruh terhadap pendapatan operasional Bank Pembiayaan Rakyat Syariah tahun 2015-2018.

Uji Koefisien Regresi secara Simultan (Uji F) Tabel C.12

Uji Signifikansi Simultan (Uji F)

ANOVAa

\begin{tabular}{|c|c|cc|}
\hline Model & $\mathrm{F}$ & \multicolumn{2}{|c|}{ Sig. } \\
\hline Regression & 12,509 & & \\
Residual & & & \\
Total & & & \\
\hline
\end{tabular}

Sumber: Hasil output SPSS Verai 23, data diolah 
Yakinah ${ }^{1}$, Kamaluddin ${ }^{2}$, Arti Damisa ${ }^{3}$, Sulaiman ${ }^{4}$

Berdasarkan output SPSS di atas dapat dijelaskan bahwa dengan tingkat signifikansi 5 $\%(0,05)$ dengan Fhitung sebesar 12,509. Tabel distribusi F dicari dengan derajat kebebasan (df) $n-k-1$, atau 48-2-1= 45, (n adalah jumlah sampel, dan $\mathrm{k}$ adalah jumlah variabel independen). Dapat dilihat pada tabel distribusi F bahwa nilai Ftabel sebesar 3,20. Hasil analisis uji F menunjukkan bahwa Fhitung > Ftabel yaitu 12,509 > 3,20, maka dapat disimpulkan bahwa pembiayaan murābahah dan musyārakah berpengaruh secara simultan atau bersamasama terhadap pendapatan operasional Bank Pembiayaan Rakyat Syariah tahun 2015-2018.

\section{PENUTUP}

\section{Kesimpulan}

Berdasarkan hasil penelitian, nilai R2 sebesar 0,357 , artinya persentase sumbangan pengaruh penyaluran pembiayaan murābahah dan musyārakah terhadap pendapatan operasional sebesar $35,7 \%$. Sedangkan sisanya sebesar $64,3 \%$ dipengaruhi atau dijelaskan oleh variabel lain yang tidak dimasukkan dalam model penelitian ini. Maka peneliti mengambil kesimpulan sebagai berikut:

1. Secara parsial, pembiayaan murābahah memiliki thitung $<$ ttabel yaitu $\quad 0,124<$ 2,01410 artinya pembiayaan murābahah tidak berpengaruh terhadap pendapatan operasional Bank Pembiayaan Rakyat Syariah Tahun 2015-2018.

2. Secara parsial, pembiayaan musyārakah memilki thitung $>$ ttabel yaitu $\quad 3,004>$
POINT Vol. 1, No. 1, Jul 2020 2,01410 artinya pembiayaan musyārakah berpengaruh terhadap pendapatan operasional Bank Pembiayaan Rakyat Syariah Tahun 2015-2018.

3. Secara simultan, pembiayaan murābahah dan musyārakah memiliki Fhitung > Ftabel yaitu $12,509>3,20$, maka dapat disimpulkan bahwa pembiayaan murābahah dan musyārakah berpengaruh secara simultan terhadap pendapatan operasional Bank Pembiayaan Rakyat Syariah Tahun 2015-2018.

\section{Saran}

Semoga adanya sumbangan terhadap penyaluran pembiayaan murabahah dan musyarakah Bank Pembiayaan Rakyat Syariah Tahun 2015-2018.

\section{DAFTAR PUSTAKA}

Abdurrahmat Fhatoni, Metodologi Penelitian \& Teknik Penyusunan Skripsi, Jakarta: Rineka Cipta, 2011.

Adiwarman Karim, Bank Islam: Analisis Fiqih dan Keuangan, Jakarta: PT Raja Grafindo Persada, 2011.

Agus Irianto, Statistik Konsep Dasar Aplikasi, dan Pengembangannya, Jakarta: Kencana Prenada Media Group, 2009.

Ascarya, Akad dan Produk Bank Syariah, Jakarta: Rajawali Pers, 2013.

Departemen Agama, Al-Qur'an dan Terjemahanya, Semarang: Toha Putra, 2010. 
Duwi Priyatno, SPSS 22 Pengolahan Data Terpraktis, Yogyakarta: CV. Andi Offset, 2014.

Dwi Suwiknyo, Kompilasi Tafsir Ayat-Ayat Ekonomi Islam, Yogyakarta: Pustaka Pelajar, 2010.

Herman Darmawi, Manajemen Perbankan, Jakarta: Bumi Aksara, 2012.

Herry Sutanto \& Khaerul Umam, Manajemen Pemasaran Bank Syariah, Bandung: Pustaka Setia, 2013.

Husein Umar, Metode Penelitian untuk Skripsi dan Tesis Bisnis. Jakarta: Rajawali Pers, 2013.

Imam Ghozali, Aplikasi Analisis Multivariate dengan Program IBM SPSS 21, Semarang: Universitas Diponegoro, 2013.

Iqbal Hasan, Analisis Data Penelitian Dengan Statistik, Jakarta: PT. Bumi Akasara, 2004.

Ismail, Perbankan Syariah, Jakarta: Kencana, 2011.

Mardani, Fiqh Ekonomi Syariah, Jakarta: Kencana, 2012.

Maulana Hasanuddin \& Jaih Mubarok, Perkembangan Akad Musyarakah, Jakarta: Kencana, 2012.

Mudrajat Kuncoro, Metode Riset untuk Bisnis dan Ekonomi, Jakarta: Erlangga, 2009.

M. Nur Rianto Al-Arif, Lembaga Keuangan Syariah, Bandung:

Pustaka Setia, 2012.
Muhammad Syafi'i Antonio, Bank Syariah: Dari Teori ke Praktik, Jakarta: Gema Insani Pers, 2016.

Muhammad Teguh, Metodologi penelitian ekonomi Teori dan Aplikasi, Jakarta: PT Raja Grafindo Persada, 2005.

Rizal Yaya, dkk., Akuntansi Perbankan Syariah, Jakarta: Selemba Empat, 2014.

Singgih Santoso, Panduan Lengkap SPSS Versi 23, Jakarta: Alex Media Komputindo, 2016.

Slamet Haryono, Analisis Laporan Keuangan Perbankan Syariah, Yogyakarta: Pustaka Sayid Sabiq, 2009.

Sugiyono, Metode Penelitian Bisnis (Bandung: Alfabeta, 2012), hlm. 88.

Sutan Remy Sjahdeini, Perbankan Syariah Produk-Produk dan Aspek-Aspek Hukumnya, Jakarta: Kencana Prenada Media Group, 2014.

Trisadini P.Usanti dan Abd Shomad, Transaksi Bank Syariah, Jakarta: Bumi Aksara, 2013.

Veithzal Rivai \& Arvian Arifin, Islamic Banking, Jakarta: PT.Bumi Aksara, 2010.

Wiroso, Produk Perbankan Syariah, Jakarta: LPFE Usakti, 2009.

Zainul Arifin, Dasar-Dasar Manajemen Bank Syariah, Jakarta: AlvaBet, 2002. 